\title{
Energy balances of eight volunteers fed on diets supplemented with either lactitol or saccharose
}

\author{
By A. J. H. VAN ES, LISETTE DE GROOT AND J. E. VOGT \\ Department of Animal Physiology, Agricultural University, 10 Haarweg, \\ 6709 PJ Wageningen, The Netherlands
}

(Received 4 March 1986 - Accepted 23 June 1986)

1. Complete $24 \mathrm{~h}$ energy and nitrogen balances were measured for eight subjects both while consuming a basal diet supplemented with $49 \mathrm{~g}$ saccharose/d (diet $\mathrm{S}$ ) and while consuming the same basal diet but supplemented with $50 \mathrm{~g}$ lactitol monohydrate/d (diet $\mathrm{L}$ ).

2. The subjects ate the two diets for $8 \mathrm{~d}$. Faeces and urine were collected for the final $4 \mathrm{~d}$. Exchange of respiratory gases (oxygen, carbon dioxide, hydrogen and methane) was measured during the final $72 \mathrm{~h}$ while the subjects stayed in an open-circuit respiration chamber, $11 \mathrm{~m}^{3}$, and simulated office work. Before eating diet $\mathrm{L}$, subjects ate $50 \mathrm{~g}$ lactitol daily for $10 \mathrm{~d}$.

3. On diets $\mathrm{L}$ and $\mathrm{S}$, faecal moisture content averaged 0.787 and $0.753 \mathrm{~g} / \mathrm{g}$ respectively, the difference being significant $(P<0.05)$. On diet $\mathrm{L}$, energy and nitrogen digestibilities and energy metabolizability averaged 0.922 , 0.836 and 0.881 respectively, and on diet $S 0.935,0.869$ and 0.896 respectively; the differences were also significant $(P<0.05)$. Urinary energy losses and $\mathrm{N}$ balances were not significantly different for the two diets.

4. In all subjects only traces of methane were produced but hydrogen production differed significantly $(P<0.05)$ for diets $L$ and $\mathrm{S}$, being 2.3 and 0.4 litres (normal temperature and pressure)/d respectively.

5. Intakes of metabolizable energy (ME) were corrected, within subjects, to energy equilibrium and equal metabolic body-weight. The corrected ME intakes did not show differences between diets. However, when on diet $\mathbf{L}$ the subjects were probably less active than when on diet $\mathbf{S}$ because differences within subjects of ankle actometer counts between diets showed a high correlation with the corresponding differences in corrected ME intakes $(r$ 0.92). Further correction of ME intake toward equal actometer activity showed a significant $(P<0.05)$ difference between diets: for maintaining energy equilibrium 5.6 (SE $0.8 ; P<0.05) \%$ more ME from diet $\mathrm{L}$ was needed than from diet $\mathrm{S}$. The reliability of this $5.6 \%$ difference depends on whether or not one ankle actometer gives an accurate picture of the subject's physical activity.

6. The energy contribution to the body is clearly smaller from lactitol than from saccharose, certainly due to the effect of lactitol on digestion, and probably also due to the effect on the utilization of ME.

Lactitol (4-O-( $\beta$-galactopyranosyl)-D-sorbitol) may be used as a sweetener in the nutrition of diabetics. It does not increase blood glucose levels (World Health Organization, 1985), since man lacks the enzyme to hydrolyse lactitol. However, lactitol is fermented by microorganisms in the large intestine, consequently only traces of it may be recovered from the faeces (Bird et al. 1985). It is not known to which end-products this fermentation leads: lactic acid or volatile fatty acids, or both, hydrogen or methane, carbon dioxide, water etc. or all the gases. These acids can be readily absorbed through the gut wall and used by the human body. The size of the energetic contribution to man's metabolism from the complete process of fermentation in the large intestine is, however, not known accurately. This is true also for the fermentation of plant fibres.

It was the aim of the present study to obtain more information on these aspects by comparing the energy balances of eight human subjects consuming the same basal diet together with either $50 \mathrm{~g}$ lactitol or $49 \mathrm{~g}$ saccharose in a reversal trial.

\section{EXPERIMENTAL}

Each of eight subjects took part in two trials, not more than 5 weeks apart. In both trials the same basal diet was eaten daily in amounts calculated to be nearly sufficient for energy equilibrium; in addition either $49 \mathrm{~g}$ saccharose $(804 \mathrm{~kJ})$ or $50 \mathrm{~g}$ lactitol monohydrate (also 
(a)

Length of sub-periods (d)
Diet
L or $S(g / d)$
Excreta collection
24 h gas exchange

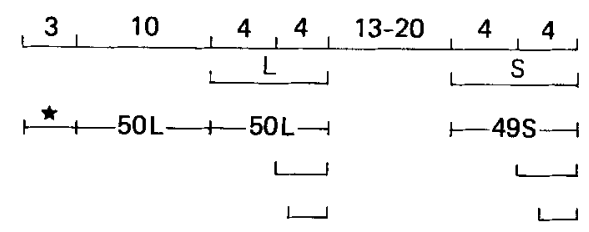

(b)

Length of sub-periods (d)
Diet
L or $S(g / d)$
Excreta collection
24 h gas exchange

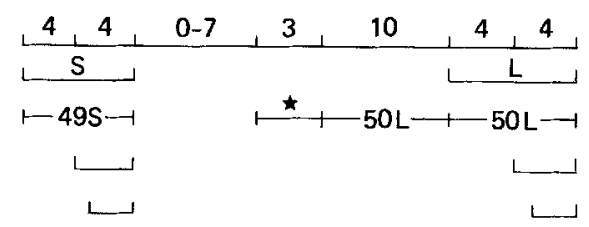

Fig. 1. Plan of experiment. (a) Four subjects, starting with the lactitol-supplemented diet (diet L), then the saccharose-supplemented diet (diet S). (b) Four subjects, starting with diet $\mathrm{S}$, then diet L.

* Adaptation to lactitol: 20,30 and $40 \mathrm{~g}$ on days 1,2 and 3 respectively.

$804 \mathrm{~kJ}$ ) were consumed daily. Four of the subjects began with the saccharose-supplemented diet, the other four began with the lactitol-supplemented diet (see Fig. 1). Before the lactitol trial, $50 \mathrm{~g}$ lactitol were eaten daily at home by each subject for $10 \mathrm{~d}$ in an attempt to adapt the hind-gut microflora. Complete energy balances were measured in each trial for the last $4 \mathrm{~d}$ of the $8 \mathrm{~d}$ feeding period. The volunteers spent nearly $3.5 \mathrm{~d}$ of the balance period in one of the two $11 \mathrm{~m}^{3}$ respiration chambers of the department for measurement of their consumption of oxygen and production of $\mathrm{CO}_{2}, \mathrm{CH}_{4}$ and $\mathrm{H}_{2}$.

\section{Subjects}

The eight subjects were chosen from a group of twelve, healthy volunteers who had consumed $50 \mathrm{~g}$ lactitol instead of sugar daily for 1 week when at home. Only those that had hardly any discomfort from this fairly large quantity were selected. They had been instructed to ingest the lactitol in four to six portions during the day and to prevent accumulation of intestinal gases by not remaining in the same posture for too long. Table 1 gives the age, sex and weight of each subject. All subjects were well informed of the aim of the study and made familiar with experimental procedures. To facilitate their adaptation to life in the respiration chambers, they occupied the chambers in the evening before the morning on which the first of three consecutive $24 \mathrm{~h}$ gas-exchange measurements began.

\section{Diets}

The basal diet, which was supplemented with either saccharose (diet S) or lactitol (diet L), was one used in earlier experiments (van Es et al. 1984) with the exception that sweetened custard was replaced by unsweetened custard and that table sugar was excluded. This diet consisted of some twenty-five separate ingredients and, except for sugar, was so formulated that it was not very different from a habitual diet eaten in The Netherlands. The approximate energy composition of the basal diet was: $42 \%$ from fat, $13 \%$ from protein, $45 \%$ from carbohydrate. Its fibre content was $2.6 \mathrm{~g} / \mathrm{MJ}$ metabolizable energy (ME). Bread, margarine and minced meat contributed most to the energy of the basal diet; bread, cheese, minced meat, milk and yoghurt contributed most to the dietary N. Subjects received the basal diet together with either $50 \mathrm{~g}$ lactitol or $49 \mathrm{~g}$ saccharose provided separately in a small box daily. A small amount of aspartame $(3 \mathrm{~g} / \mathrm{kg})$ was mixed through the lactitol so that the mixture had nearly the same sweetness as the saccharose.

All ingredients of the daily portions were sampled separately and weighed to the nearest 
Table 1. Details of subjects, their gross energy $(G E)$ intakes, digestibilities of energy $\left(\mathrm{d}_{\mathrm{E}}\right)$ and nitrogen $\left(\mathrm{d}_{\mathrm{N}}\right)$, metabolizability of energy $(\mathrm{q})$, faecal dry matter and combustible gas release when fed on the lactitol-supplemented diet (diet $L)$ and when fed on the saccharosesupplemented diet (diet $S$ )

\begin{tabular}{|c|c|c|c|c|c|c|c|c|c|c|c|c|}
\hline \multirow{2}{*}{$\begin{array}{c}\text { Expt } \\
\text { no. }\end{array}$} & \multirow[b]{2}{*}{ Diet } & \multirow{2}{*}{$\begin{array}{c}\text { Subject } \\
\text { no. }\end{array}$} & \multirow[b]{2}{*}{ Sex } & \multirow{2}{*}{$\begin{array}{c}\text { Age } \\
\text { (years) }\end{array}$} & \multirow{2}{*}{$\begin{array}{c}\mathrm{Wt} \\
(\mathrm{kg})\end{array}$} & \multirow{2}{*}{$\begin{array}{c}\mathrm{GE}^{*} \\
(\mathrm{~kJ} / \mathrm{d})\end{array}$} & \multirow[b]{2}{*}{$d_{\mathbf{E}}$} & \multirow[b]{2}{*}{$q^{\dagger}$} & \multirow[b]{2}{*}{$d_{\mathrm{N}}$} & \multirow{2}{*}{$\begin{array}{l}\text { Proportion } \\
\text { of } \\
\text { dry matter } \\
\text { in faeces }\end{array}$} & \multicolumn{2}{|c|}{ Gas released $\ddagger(1 / d)$} \\
\hline & & & & & & & & & & & Hydrogen & Methane \\
\hline 1 & S & 1 & \multirow[t]{2}{*}{$\hat{\sigma}$} & \multirow[t]{2}{*}{20} & $62 \cdot 3$ & 10139 & 0.916 & 0.876 & 0.868 & $0 \cdot 202$ & 0.4 & $\operatorname{tr}$ \\
\hline 3 & $\mathrm{~L}$ & 1 & & & $61 \cdot 8$ & 10138 & 0.895 & 0.856 & 0.803 & $0 \cdot 200$ & $2 \cdot 2$ & $\mathrm{tr}$ \\
\hline 1 & $\mathrm{~L}$ & 2 & \multirow[t]{2}{*}{6} & \multirow[t]{2}{*}{23} & $76 \cdot 2$ & 10113 & $0 \cdot 907$ & 0.857 & 0.834 & $0 \cdot 182$ & $4 \cdot 3$ & tr \\
\hline 3 & $\mathrm{~S}$ & 2 & & & $75 \cdot 6$ & 10112 & 0.937 & $0 \cdot 893$ & 0.879 & 0.234 & 0.5 & $\operatorname{tr}$ \\
\hline 2 & $\mathbf{S}$ & 3 & \multirow[t]{2}{*}{ q } & \multirow[t]{2}{*}{19} & $63 \cdot 8$ & 8567 & 0.940 & 0.901 & 0.857 & 0.262 & 0.4 & $\operatorname{tr}$ \\
\hline 4 & $\mathrm{~L}$ & 3 & & & $64 \cdot 7$ & 8574 & 0.947 & 0.902 & 0.863 & 0.228 & $3 \cdot 5$ & $\operatorname{tr}$ \\
\hline 2 & $\mathrm{~L}$ & 4 & \multirow[t]{2}{*}{ 우 } & \multirow[t]{2}{*}{21} & $59 \cdot 9$ & 10118 & 0.929 & 0.893 & 0.855 & 0.221 & 0.7 & $\operatorname{tr}$ \\
\hline 4 & $\mathrm{~S}$ & 4 & & & $59 \cdot 2$ & 10127 & 0.933 & 0.897 & 0.858 & 0.241 & 0.3 & $\mathrm{tr}$ \\
\hline 6 & $\mathrm{~L}$ & 5 & \multirow[t]{2}{*}{ q } & \multirow[t]{2}{*}{24} & $69 \cdot 0$ & 9980 & 0.948 & 0.910 & 0.885 & 0.192 & 1.7 & $\operatorname{tr}$ \\
\hline 8 & $S$ & 5 & & & 68.9 & 9967 & 0.942 & 0.902 & 0.870 & 0.264 & 0.2 & $\mathrm{tr}$ \\
\hline 6 & $\mathbf{S}$ & 6 & \multirow[t]{2}{*}{$q$} & \multirow[t]{2}{*}{25} & $63 \cdot 1$ & 10134 & 0.923 & 0.886 & 0.853 & 0.314 & 0.3 & $\mathrm{tr}$ \\
\hline 8 & $\mathrm{~L}$ & 6 & & & $63 \cdot 8$ & 10113 & 0.904 & 0.864 & 0.759 & 0.270 & $2 \cdot 7$ & $\mathrm{tr}$ \\
\hline 5 & $S$ & 7 & \multirow[t]{2}{*}{$\delta$} & \multirow[t]{2}{*}{20} & $65 \cdot 0$ & 11749 & 0.945 & 0.908 & 0.882 & 0.205 & 0.6 & $\operatorname{tr}$ \\
\hline 7 & $\mathrm{~L}$ & 7 & & & $65 \cdot 4$ & 11749 & 0.927 & 0.891 & 0.855 & 0.208 & 1.8 & tr \\
\hline 5 & $\mathrm{~L}$ & 8 & \multirow[t]{6}{*}{$\hat{\sigma}$} & \multirow{2}{*}{26} & 59.0 & 10142 & 0.922 & 0.878 & 0.832 & 0.204 & 1.8 & $\mathrm{tr}$ \\
\hline 7 & $S$ & 8 & & & 58.8 & 10143 & 0.943 & 0.905 & 0.883 & 0.257 & 0.2 & $\mathrm{tr}$ \\
\hline & Diet $S$ & Mean & & & $64 \cdot 6$ & 10117 & 0.935 & 0.896 & 0.869 & 0.247 & 0.4 & \\
\hline & \multirow{3}{*}{ Diet $\mathbf{L}$} & SD & & & 5.5 & 853 & 0.010 & 0.011 & 0.012 & 0.036 & $0 \cdot 1$ & \\
\hline & & Mean & & & $65 \cdot 0$ & 10116 & 0.922 & 0.881 & 0.836 & 0.213 & $2 \cdot 3$ & \\
\hline & & $\mathrm{SD}$ & & & $5 \cdot 5$ & 851 & $0 \cdot 019$ & 0.021 & 0.039 & 0.027 & $1 \cdot 1$ & \\
\hline
\end{tabular}

tr, trace (less than 0.07 litres/d).

* GE of saccharose or lactitol included. $†$ Metabolizable energy expressed as a proportion of GE. $\ddagger$ Dry volume at normal temperature $\left(0^{\circ}\right)$ and pressure $(760 \mathrm{mmHg})$.

$0 \cdot 1 \mathrm{~g}$, either before the whole experiment or, for fluids like milk, yoghurt, etc., for a 2-3 d period before and during each balance trial. Portions and samples were stored at low temperature $\left(5^{\circ}\right.$ or $\left.-20^{\circ}\right)$, when necessary.

Subjects were instructed to eat the diets to the last bit and drop. Most of them were students of the Human Nutrition Department and understood the necessity of doing so when comparing diets differing by one ingredient present only in a small quantity.

\section{Excreta}

Collection of faeces and urine started at $\mathbf{0 7 . 3 0}$ hours after urination on the first day of the collection period and continued for $4 \mathrm{~d}$. For preservation of the urine a small amount of mercuric iodide was used. All urine was stored at $5^{\circ}$ during the collection period. Urine was sampled a few days after the collection was completed; some was dried in vacuo at room temperature for bomb calorimetry and the remainder was stored deep-frozen for further analysis.

Faeces were also stored at $-20^{\circ}$ during the collection period, then freeze-dried a few days afterwards. 


\section{Measurement of respiratory-gas exchange}

The same two open-circuit respiration chambers of $11 \mathrm{~m}^{3}$ of earlier studies (van Es et al. 1984) were used in the present study. Each chamber is equipped with a bed, two chairs, a bicycle home-trainer, a wash-stand-writing desk, a radio, a television set and a telephone. Two small airlocks serve for the supply of food and removal of excreta. The volume of the air drawn from each chamber was measured by a dry gas meter. Samples of in- and out-going air were collected in glass tubes over mercury (composite sample). The $24 \mathrm{~h}$ composite samples were analysed volumetrically with a Sonden apparatus for $\mathrm{O}_{2}$ and $\mathrm{CO}_{2}$ contents. These samples were also analysed for $\mathrm{H}_{2}$ and $\mathrm{CH}_{4}$ contents, by gas-solid chromatography. For $\mathrm{H}_{2}$ analysis a molecular sieve and a thermal conductivity detector were used (lower limit of detection $10 \mu \mathrm{l} / \mathrm{l}$ ). For $\mathrm{CH}_{4}$ analysis, porapak $\mathrm{Q}$ and a flame ionization detector were used (lower limit of detection $1 \mu \mathrm{l} / \mathrm{l}$ ). Calibration was done using dilutions of pure $\mathrm{H}_{2}$ and $\mathrm{CH}_{4}$ in air. At both the start and the end of each $24 \mathrm{~h}$ experiment, samples of air from the chamber were taken and analysed for $\mathrm{O}_{2}$ and $\mathrm{CO}_{2}$ contents. Heat production was calculated using Brouwer's (1965) equation and $\mathrm{O}_{2}$ consumption, $\mathrm{CO}_{2}$ production and urinary $\mathrm{N}$ excretion with addition of a correction for $\mathrm{H}_{2}$ production (Brouwer, 1958):

$$
\mathrm{H}=16 \cdot 175 \mathrm{O}_{2}+5.021 \mathrm{CO}_{2}-5.987 \mathrm{~N}_{\mathrm{u}}-4.5 \mathrm{H}_{2} \text {, }
$$

where $\mathrm{H}$ is heat production $(\mathrm{kJ} / \mathrm{d}), \mathrm{O}_{2}$ is $\mathrm{O}_{2}$ consumption (l at normal temperature and pressure (NTP)/d), $\mathrm{CO}_{2}$ and $\mathrm{H}_{2}$ are $\mathrm{CO}_{2}$ and $\mathrm{H}_{2}$ production respectively (l at NTP/d), $\mathrm{N}_{\mathrm{u}}$ is urinary nitrogen $(\mathrm{g} / \mathrm{d})$.

The equipment was checked by burning alcohol; recoveries of $\mathrm{O}_{2}$ and $\mathrm{CO}_{2}$ were 0.978 , $1.003,0.988,0.989,0.983$ and $0.978,0.998,0.978,0.984,0.984$ respectively. Moreover, the $\mathrm{O}_{2}$ analysis was checked by analysis of fresh outdoor air during each $24 \mathrm{~h}$ period of the experiment.

Chamber temperatures were $22^{\circ}$ from 07.30 to 22.30 hours and $2^{\circ}$ lower during the night. Relative humidity was kept at about $70 \%$.

Subjects went to bed at approximately 23.00 hours and rose between 07.30 and 08.00 hours. They ate breakfast, lunch and dinner at about $08.30,12.30$ and 18.00 hours respectively and cycled for approximately $15 \mathrm{~min}$ at moderate speed but without a work load on the home-trainer at $08.45,12.15,13.15,17.30$ and 22.30 hours. They were otherwise free to do what they liked, except physical exercise, other than moving occasionally from chair to desk, etc. Subjects were asked to behave similarly in both experiments. While in the respiration chamber they wore a watch actometer (Saris \& Binkhorst, 1977) above the right ankle to obtain some information on their physical activity. They occupied the same chamber and were wearing the same actometer in both experiments. The actometers had the normal date indication, i.e. this indication changed after the small hand of the watch had made two complete rotations.

\section{Analyses}

$\mathrm{N}$ in foods and excreta was determined by the Kjeldahl method using $\mathrm{Hg}$ as a catalyst (International Organization for Standardization, 1979).

Heat of combustible energy was determined using a static bomb calorimeter. Wet samples were dried first, by freeze-drying (vegetables, faeces), at room temperature in vacuo (fluids; dried in a polyethylene bag and after drying combusted with the bag) or at $70^{\circ}$ in a forced-air drying oven. Samples of cheese, minced meat, sausages and saveloy were mixed with silica gel powder, homogenized and weighed in polyethylene bags. Samples of margarine were also weighed in such bags. Bags with contents were combusted.

All analyses were done at least in duplicate on each sample. 
Statistical analysis

Variation in results between subjects was shown by standard deviations. Student's $t$ test, usually for paired observations, was used to determine whether differences were statistically significant.

\section{Ethics}

The study was approved by the Ethical Committee of the Department of Human Nutrition of the Agricultural University.

\section{RESULTS}

\section{Diets and subjects}

All dietary items were eaten completely. Two volunteers on the diet L sometimes had unpleasant accumulation of intestinal gas which disappeared soon after taking a few steps or changing position.

One volunteer developed a bladder inflammation $1 \mathrm{~d}$ before the start of the experimental period on diet $\mathrm{L}$. The experiment was broken off and started anew nearly 2 months later after complete recovery.

Gross energy (GE) intake averaged 10.12 (SD 0.85) MJ/d and N intake $12 \cdot 2$ (SD 0.9) g/d. Combustible energy in lactitol or saccharose was $6 \cdot 8-9 \cdot 4 \%$ of GE. Slight differences in GE for the two diets ingested by the same subject were due to small variation in composition of fresh food items.

Energy and $N$ losses in faeces and urine, production of combustible gases and $M E$

In the present study digestibilities of energy and $\mathrm{N}$ and metabolizabilities showed only small variations between subjects and these are similar to values in earlier work (Table 1; van Es et al. 1984). Tables 1 and 2 give the main information on energy exchanges and Table 3 gives the differences between diets for various values within subjects; results for diet $\mathrm{S}$ have been subtracted from those of diet L. On diet $\mathrm{L}$ the faeces contained more water, the digestibilities of energy and especially of $\mathrm{N}$ were lower and the metabolizability of energy was lower also. The lower $\mathrm{N}$ digestibility resulted, as expected, in a lower urinary $\mathrm{N}$ excretion (mean $10.8(\mathrm{SD} 1.0) \mathrm{g} / \mathrm{d}$ ) by $0.54(\mathrm{SE} 0.21) \mathrm{g} / \mathrm{d}$ but urinary energy losses, expressed as a proportion of GE (mean 0.038 (SD 0.003 )), did not differ significantly between diets.

Only traces of $\mathrm{CH}_{4}$ (less than 0.07 litres/d) were produced by all subjects on both diets; a difference between diets could not be detected. Subjects when fed on diet $\mathrm{L}$ produced more $\mathrm{H}_{2}$ than when fed on diet S (2.3 (SD 1.1) v. $0 \cdot 4$ (SD 0.1) 1 NTP/d); the mean difference within subjects, expressed in units of energy, was 25 (SE 5) kJ/d when 1 litre $\mathrm{NTP}_{2}$ is assumed to contain $12.60 \mathrm{~kJ}$.

ME was calculated by subtracting energies in faeces, combustible gases and urine from GE. ME as a proportion of GE, i.e. the metabolizability $q$, was lower for diet L by 0.015 (SE 0.005).

\section{$N$ balances}

$\mathrm{N}$ balances averaging -0.4 (SD 0.7 ) $\mathrm{g} / \mathrm{d}$ did not differ significantly between diets (Table 2). Therefore ME values were not corrected to zero $\mathrm{N}$ balance.

\section{Respiratory quotients $(R Q)$, heat production $(H)$, energy retention $(R E)$ and energy requirement}

Table 2 gives these values. $\mathrm{RE}(\mathrm{kJ} / \mathrm{d})$ has been calculated by subtracting $\mathrm{H}(\mathrm{kJ} / \mathrm{d})$ from ME. $\mathrm{H}$ was calculated from respiratory gas exchange, including $\mathrm{H}_{2}$, and urinary $\mathrm{N}$ as mentioned previously. RQ values, uncorrected for protein oxidation were 0.827 (SD 0.011) 


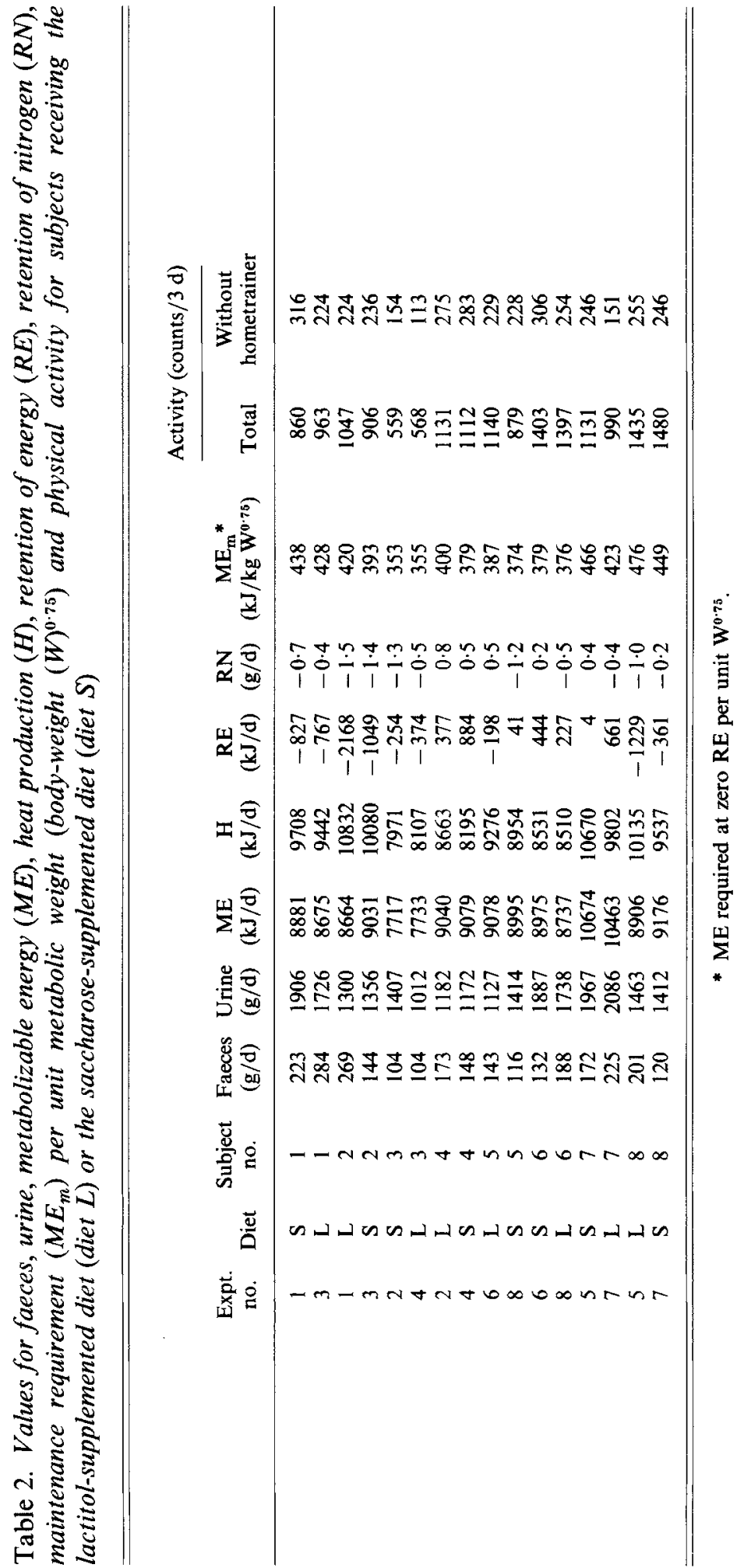




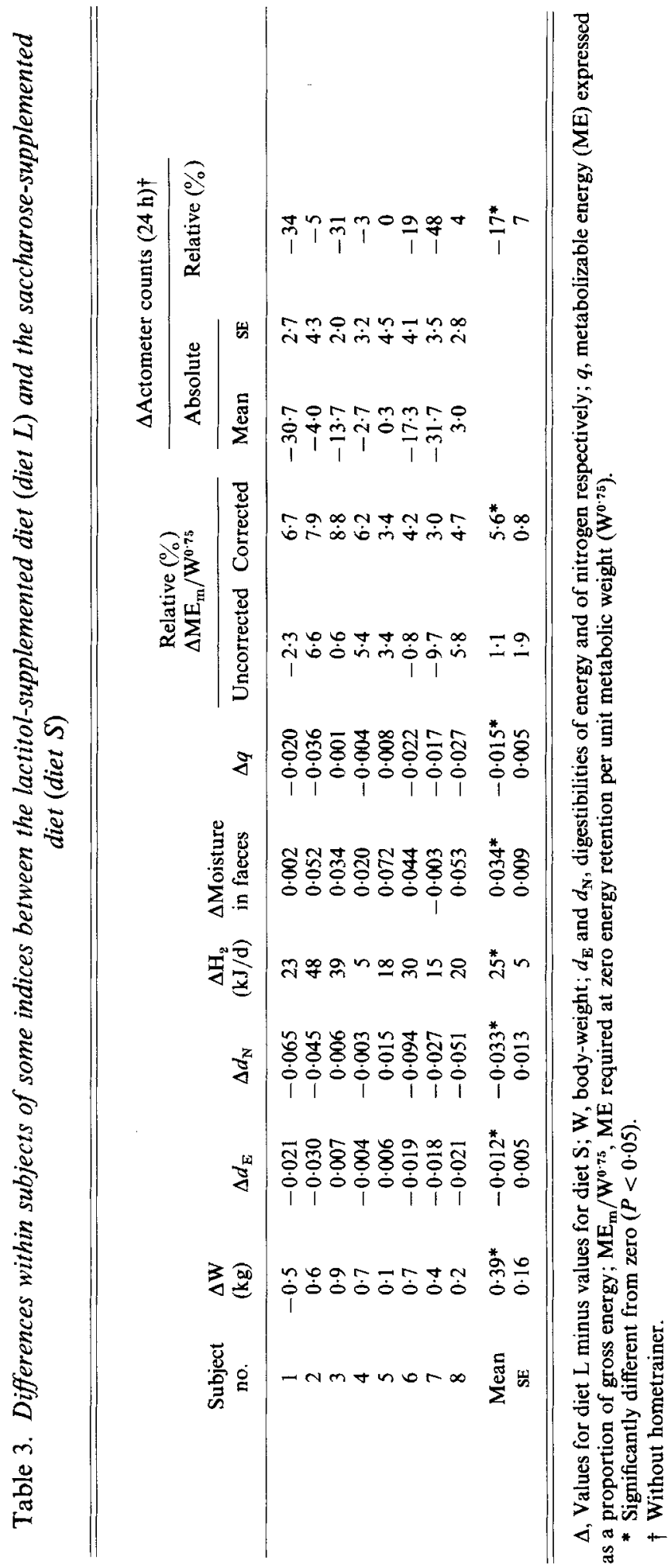


and 0.837 (SD 0.010 ) for diets $\mathrm{L}$ and $\mathrm{S}$ respectively; the difference within subjects was -0.010 (SE $0.0025, P<0.05$ ).

RE varied from -2168 to $884 \mathrm{~kJ} / \mathrm{d}$ and, within subjects, usually differed for the two diets. When RE was positive, part of the diet had been used for energy deposition, whereas negative values of RE indicate mobilization of energy stores from the body to make up for the gap between $\mathrm{ME}$ intake and $\mathrm{ME}$ requirement. Comparison of the value of the $\mathrm{ME}$ of the two diets for maintaining the body in the same state, i.e. for keeping it in energy equilibrium, is easiest when RE values are zero and live weights are similar or standardized. In earlier work (van Es et al. 1984) with diets similar to diet $S$ it was found that the conversion of ME into positive RE had an efficiency of 0.9 , whereas for a negative RE an extra amount of $\mathrm{ME}$, equal in quantity to the absolute value of $\mathrm{RE}$, sufficed to restore energy equilibrium $(\mathrm{RE}=0)$. Thus also in the present study $\mathrm{ME}$ requirements for maintenance $\left(\mathrm{ME}_{\mathrm{m}}\right)$ were calculated, in the case of positive $R E$ values by subtracting $\mathrm{RE} / 0.9$ from ME and, in the case of negative RE values, by adding the absolute value of RE to ME. Finally, to correct for the small variation in body-weights within and between subjects, $\mathrm{ME}_{\mathrm{m}}$ was divided by the corresponding metabolic body-weight (bodyweight ${ }^{0.75}(\mathrm{~kg})$ ). The final values are given in Table 2 . The differences between diets within subjects averaged $4(\mathrm{SE} 8) \mathrm{kJ} / \mathrm{kg}$ body-weight $\mathrm{t}^{0.75}$ and, expressed as a percentage of the average $\mathrm{ME}_{\mathrm{m}} / \mathrm{kg}$ body-weight ${ }^{0 \cdot 75}$ for both diets, the difference was $1 \cdot 1$ (SE 1.9$) \%$.

\section{Actometer counts}

The $24 \mathrm{~h}$ actometer counts within subjects showed considerable variation, mainly due to variation during the home-trainer exercise periods. The way in which the feet were placed on the pedals gave marked variation in the actometer count. Since the speed and duration of the activity in the home-trainer periods were kept constant, it was considered better to exclude the counts for these periods. Thus all actometer counts from home-trainer activity were subtracted from the total. This revealed that within subjects home-trainer-free actometer counts were 17 (SE 7) \% lower on diet $\mathrm{L}$ than on diet $\mathrm{S}$ (Table 3 ). These actometer differences $(x, \%$ of subject's mean) correlated $(r 0.92, P<0.05)$ with the differences within subjects due to diet of $\mathrm{ME}_{\mathrm{m}} / \mathrm{kg}$ body-weight ${ }^{0 \cdot 75}(y, \%$ of subject's mean). The relation was:

$$
y=0.26(\text { SE } 0.02) x+5.63 \text { (residual SD } 0.9) \text {. }
$$

\section{DISCUSSION}

Table 3 shows, fairly uniformly for all subjects, that diets $L$ and $S$ were digested differently. The differences were consistent with the expectation that saccharose would be absorbed from the small intestine whereas lactitol would reach the large intestine and be fermented by micro-organisms. The occurrence of more $\mathrm{H}_{2}$ on diet $\mathrm{L}$, in a quantity of about $3 \%$ of the energy of the lactitol, is evidence of this expectation. The low $\mathrm{CH}_{4}$ production was probably due to the low age of our subjects. The occurrence of $\mathrm{H}_{2}$ and near-absence of $\mathrm{CH}_{4}$ may indicate that the type of fermentation in the case of lactitol results in lactic acid as the end-product rather than the volatile fatty acids acetic, propionic and butyric acids, or a mixture of these four acids (Bryant, 1979).

Fermentation means microbial activity, so very probably microbial growth. The increased energy supply to the micro-organisms expected on diet $\mathrm{L}$ would permit them to incorporate the $\mathrm{N}$ of digesta entering the large intestine; this incorporated $\mathrm{N}$ was voided with the faeces and lowered the energy and $\mathrm{N}$ digestibilities. On diet $\mathrm{S}$, micro-organisms might be expected to degrade some of the proteins entering the large intestine to $\mathrm{NH}_{3}$ in order to supply themselves with energy. The $\mathrm{NH}_{3}$ will be absorbed into the blood, eventually to be excreted 
in urine after conversion to urea. Although this could explain the lower $\mathrm{N}$ excretion into the urine on diet $\mathrm{L}$, it does not explain the hardly changed urinary energy excretion. Experiments with animals, however, have shown that increased fermentation in the gastrointestinal tract is usually accompanied by combustible side-products of fermentation which are excreted with the urine (Blaxter, 1962).

The metabolizability, $q$, of the two diets differed slightly more than the energy digestibilities because of differences in $\mathrm{H}_{2}$ production. The mean difference amounted to 0.015 (SE $0.005 ; P<0.05$ ) or, expressed as a percentage of the average, $1.7 \%$. This difference is attributed to lactitol replacing saccharose in an amount of only $6.8-9.4 \%$ of the GE intake. Extrapolation to $100 \%$ lactitol $v .100 \%$ saccharose would suggest a lower $q$ for lactitol by about 20 (SE 7)\%.

ATP is the main energy compound needed for maintenance. According to our knowledge of the metabolic pathways, monosaccharides resulting from saccharose digestion provide more ATP per unit food energy than do either lactic acid or the volatile fatty acids which are the expected end-products of the fermentation of lactitol. Moreover, during fermentation the micro-organisms produce heat. This explains why the ME from a diet undergoing partial microbial fermentation is expected to have a lower potential for ATP production and thus a lower energy value for maintenance. This is especially true for fermentation with volatile fatty acids as end-products, but less so when lactic acid is the main end-product.

Table 3 does not show a significant difference in the maintenance requirements $\left(\mathrm{ME}_{\mathrm{m}} / \mathrm{kg}\right.$ body-weight $t^{0.75}$ ) between the two diets when not corrected for differences in actometer counts. Within subjects differences for the two diets varied from -9.7 to $6.6 \%$. The values of $\mathrm{ME}_{\mathrm{m}} / \mathrm{kg}$ body-weight $t^{0.75}$ within subjects over periods of several months in our earlier studies, had a coefficient of variation of $2-3 \%$, thus a difference for the two experiments with the same subject $\sqrt{ } 2$ times as much, i.e. $2 \cdot 8-4 \cdot 2 \%$ (de Boer, 1985). Thus all differences found within subjects lie in the $95 \%$ confidence interval. However, the distribution of the differences is far from normal; especially for subject no. 7 who had a rather high maintenance requirement on diet $\mathrm{S}$. Thus, it was considered useful to compare within subjects the relative differences in $\mathrm{ME}_{\mathrm{m}} / \mathrm{kg}$ body-weight ${ }^{0.75}$ with those of the actometer counts. Wearing the actometer above the ankle-joint gave an excessive number of counts during activity on the home-trainer which amounted to about 0.75 of total counts. Because home-trainer activity was standardized with regard to duration and intensity, it was considered better to compare within subjects the actometer counts for the remaining $22 \mathrm{~h}$ and $45 \mathrm{~min}$ of the day with the differences in weight-standardized energy requirement $\left(\mathrm{ME}_{\mathrm{m}} / \mathrm{kg}\right.$ body-weight $\left.{ }^{0.75}\right)$.

Against the expectation of more flatulence on diet $\mathrm{L}$, requiring a change of position more often, six of the eight subjects had lower home-trainer-free actometer counts on diet $\mathrm{L}$ than on diet $\mathbf{S}$. There does not exist any evidence that reduction in net energy supply by about $5 \%$, as was the case for diet $\mathrm{L} v$. diet $\mathrm{S}$, would lead to lower physical activity. The relation between the differences within subjects in these counts and the differences within

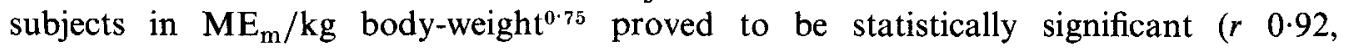
$P<0.05$ ). Using the regression equation (eqn (1)), the relative differences of $\mathrm{ME}_{\mathrm{m}} / \mathrm{kg}$ body-weight ${ }^{0.75}$ within subjects due to diet were corrected toward equal home-trainer-free actometer counts on both diets (Table 3 ). The results show a 5.6 (SE $0.8, \mathrm{P}<0.05) \%$ higher maintenance requirement, at equal activity, on diet $\mathrm{L}$ than on diet S. Extrapolated to $100 \%$ lactitol $v .100 \%$ saccharose this would mean an energy value of ME for maintenance of lactitol considerably lower than that for saccharose (by some 60 (SE 10)\%). This result, however, has to be considered with some caution, because the previously-mentioned correction for activity depends completely on one ankle-actometer giving a true picture of 
home-trainer-free activity and because of the extrapolation made. A study of the activity diaries made by the subjects during the calorimeter sessions revealed only clear differences in behaviour for subject no. 7 who had been typewriting actively when on diet $S$ but not when on diet $\mathbf{L}$.

From the results it appears that replacing $49 \mathrm{~g}(804 \mathrm{~kJ})$ saccharose by $50 \mathrm{~g}(804 \mathrm{~kJ})$ lactitol monohydrate in a normal diet leads to increased fermentation in the large intestine. As a result the digestibilities of dietary energy and $\mathrm{N}$ decrease, some $\mathrm{H}_{2}$ is produced, metabolizability of dietary energy decreases while very probably the efficiency of the utilization of the ME also decreases. Extrapolation of the results would suggest that the GE of lactitol would contain 20 (SE 7) \% less ME than that of saccharose. With regard to the value of the ME to supply energy for maintaining the body in energy equilibrium, $1 \mathrm{~kJ} \mathrm{ME}$ of lactitol would probably supply 60 (SE 10$) \%$ less than $1 \mathrm{~kJ}$ ME of saccharose.

The authors wish to thank Miss H. de Jong, Mr W. A. van Kranenburg, Mr M. J. N. Los and $\mathrm{Mr}$ L. J. G. M. Bongers for their careful assistance in preparing meals, care for the experimental subjects and analytical work. The authors also thank the volunteers for their enthusiastic co-operation and the Akademie Diedenoort at Wageningen for preparation of part of the food.

\section{REFERENCES}

Bird, S. P., Hewitt, D. \& Gurr, M. I. (1985). Proceedings of the Nutrition Society 44, 40A.

Blaxter, K. L. (1962). The Energy Metabolism of Ruminants, pp. 231-232. London: Hutchinson.

Brouwer, E. (1958). In Proceedings of the 1st Symposium on Energy Metabolism, European Association for Animal Production Publication no. 8, pp. 182-192 [G. Thorbek and H. Aersoe, editors]. Copenhagen: Statens Husdyrbrugsudvalg.

Brouwer, E. (1965). In Proceedings of the 3rd Symposium on Energy Metabolism, European Association for Animal Production Publication no. 11, pp. 441-443 [K. L. Blaxter, editor]. London: Academic Press.

Bryant, M. P. (1979). Journal of Animal Science 48, 193-201.

de Boer, J. O. (1985). Energy requirements of lean and overweight women, assessed by indirect calorimetry, pp. 20-33. PhD Thesis, University of Wageningen.

International Organization for Standardization (1979). International Standard no. 5983.

Saris, W. H. M. \& Binkhorst, R. A. (1977). European Journal of Applied Physiology 37, 229-335.

van Es, A. J. H., Vogt, J. E., Niessen, J. E., Veth, J., Rodenburg, L., Teeuwse, V., Dhuyvetter, J., Deurenberg,

P., Hautvast, J. G. A. J. \& van der Beek, E. (1984). British Journal of Nutrition 52, 429-442.

World Health Organization (1985). Food Additives Series no. 18, p. 91. Geneva: WHO. 